\title{
Chromosome numbers and taxonomy in Cryptocoryne (Araceae). II
}

\author{
J. C. Arends, J. D. Bastmeijer and N. Jacobsen
}

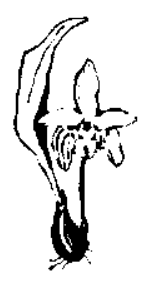

\begin{abstract}
Arends, J. C., Bastmeijer, J. D. \& Jacobsen, N. 1982. Chromosome numbers and taxonomy in Cryptocoryne (Araceae). Il. - Nord. J. Bot. 2: 453-463. Copenhagen. ISSN 0107-055X.
\end{abstract}

\begin{abstract}
Chromosome numbers for 38 species of Cryprocoryne are reported, 16 of which have not been reported earlier. About $90 \%$ of the species of Cryptocoryne have now been investigated cytologically. On the basis of chromosome numbers, morphology, and distribution, it is possible to distinguish some 24 groups within the species investigated. The chromosome numbers represent a heteroploid series which is based on the (secondary) base numbers $10,11,14,15,17$, and 18 . Evidence is given that $2 n=36$ is the more primitive one. Evolution on the chromosome level has most likely gone in the direction of a reduction in numbers. Two new species, Cryptocoryne amicorum De Wit \& N. Jacobsen and C. keei N. Jacobsen, are described.
\end{abstract}

J. C. Arends, Dept of Plant Taxonomy and Plant Geography, Agricultural Univ., P.O. Box 80J0, 6700 ED Wageningen, The Netherlands. J. D. Basimeijer, Oude Roswinkelerweg 72, 7822 AG Emmen, The Netherlands. N. Jacobsen, Inst. of Sysiematic Botany, Gothersgade 140, DK- 1123 Copenhagen K, Denmark.

\section{Introduction}

This paper is a continuation of previous studies in Cryptocoryne (Jacobsen 1976, 1977, 1980a).

\section{Material and methods}

Many specimens were kindly provided for investigation by several colleagues. Part of the material was collected in Sarawak and the Malay peninsula during a collection tour in September 1978. A description of some of the localities in Sarawak was given in Schulze (1971), and Jacobsen (1979a).

At the Copenhagen laboratory root tips were pretreated in $\alpha$-monobrome-naphtalene, fixed in lactid acid at $0^{\circ} \mathrm{C}$, stained in pyronine following the method of Jacobsen (1957), and squashed with a plastic cover slip method described by Östergreen \& Heneen (1962). At the Wageningen laboratory the orcein staining method as outlined by Arends \& Laan (1978) was employed. Voucher specimens of the Jacobsen collections are de- posited at $\mathrm{C}$ and of the Bastmeijer collections at WAG. Herbarium specimens have been studied from the following herbaria: B, BK, BKF, C, CAL, CAMB, E, FI, G, GH, K, KLU, L, LAE, LD, M, MO, NY, P, SAR, SING, US, W, WAG, and Z. Herbarium material from these herbaria was also used for the determinations and the distributions given in Jacobsen (1977).

\section{Chromosome numbers}

Cryptocoryne striolata Engl. $\quad 2 \mathbf{n}=\mathbf{2 0}$

C. gracilis De Wit, C. "ongii" (Tomey 1978).

Material: Malaysia, Sarawak: Kpg. Panchor, NJ 78-1;6 miles Pakan - Entabai, NJ 78-3; 4 miles Pakan - Sarikei, Nj 78-4; Sg. Entabai, NJ 78-5; Sg. Selalang, NJ 78-8; 70 miles Kuching - Simmanggang, NJ 78-12; Batu Besai, NJ 78-18; Kpg. Monkus, NJ 78-52.

Arends \& Laan (1979) reported the same number. There has been some uncertainty as to the identity of $C$. striolata because the type specimen (Beccari 1240, FI) 
had a limb of the spathe which had not opened. Material collected in Sarawak in 1978, however, leaves no doubt as to the identity of the species. The characteristic "striateness" found on the leaves of the type specimen was best seen in dried specimens and was not always present.

The limb of the spathe lacked a collar, but a collar zone was indicated by a more or less dark, purple colour which could also consist of a more or less densely spotted area. The upper part of the limb may be of the same colour as the collar, or more yellowish.

\section{Cryptocoryne keei N. Jacobsen sp. nov. $2 n=20$}

Folia $10-40 \mathrm{~cm}$ longa, lamina anguste ovata, obscure viridi, valde bullosa, subtus saepe striata. Spatha circiter $5 \mathrm{~cm}$ longa, limbo circiter $2 \mathrm{~cm}$ longo, anguste ovato, plus minus cucullato, purpureo, plus minus laevi, collari nullo. Stigma ovatum; corpora olfactoria irregulariter lobata, plus minus connata.

Typus: Hnery Ong Kee Chuan s.n., prope oppidum Bau, Sarawak (C holotypus, WAG isotypus).

Material: Malaysia, Sarawak: Bau, September 1978, NJ 78-53.

Material collected near Banjarmasin, Indonesia, (leg. Stroh (= NJ 3123), leg. Korthaus (= Bast 398, = NJ 3243)) resembles $C$. $k e e i$ in the vegetative parts and has $2 n=20$. It is not certain if this Banjarmasin material belongs to $C$. keei. Inflorescences of $C$. keei, only known from herbarium material, indicate relations with $C$. striolata.

\section{Cryptocoryne ciliata (Roxb.) Schott $2 n=22,33$}

C. elata Griff., $C$. drymorrhiza Zipp., nom. nud.

Material: $2 \mathrm{n}=22$. Thailand: Nan Lumliang, NJ 77-100. Malaysia, Sarawak: Kuching, NJ 78-34; 12.5 miles Batu Kitang-Bau, NJ 78-39; Kpg. Stutong, NJ 78-45. - Johore: Kota Tinggi, NJ 78-56. - Cult.: NJ 3047.

2n $=33$. Malaysia, Sarawak: Kpg. Stutong, NJ 78-46.

At the locality at Kpg. Stutong, Sarawak, diploid and triploid forms were growing together in abundance. A very narrow-leaved form, supposed to come from the Malay peninsula (NJ 3047), also proved to have $2 \mathrm{n}=$ 22.

\section{Cryptocoryne spiralis (Retz.) Wydler $2 n=33,66$, and ca. 132}

C. huegelii Schott, C. rortuosa Blatt. \& McCann.

Material: $2 \mathrm{n}=33$. India: Pivavan, leg. Cook (= NJ 3129a). $2 n=66$. India: Qvilandi, leg. Cook (= NJ 3125); Madokal, Savantwadi, leg. van der Maessen (= NJ 3166); Goa - Karnataka, leg van der Maessen (= NJ 3167); Goa - Belgaum, leg. van der Maessen (= Bast 405 ).

$2 \mathrm{n}=$ ca. 132. India: Pivavan, leg. Cook (= NJ 3129b).
Sarkar et al. (1979) reported $2 \mathrm{n}=90$ for this species. The material collected by C. D. K. Cook at Pivavan proved to consist of two different forms. They had a different leaf-form, and the plants with $2 n=33$ flowered very quickly. There are no data concerning their distribution at the locality where they were collected. The plants with $2 n=33$ are no doubt haploids of plants with $2 n=66$, while the plants with $2 n=$ ca. 132 are "tetraploids" of plants with $2 n=66$.

\section{Cryptocotyne beckettii Trimen $2 n=28$}

C. petchii Alston.

Material: Sri Lanka: Halloluwa, NJ 23-9.

\section{Cryptocoryne walkeri Schott $2 n=\mathbf{4 2}$}

C. Iutea Alston, $C$. lutea Alston var. minor Alston, $C$. legroi De Wit, $C$. walkeri Schott var. lutea (Alston) Rataj, C. walkeri Schott var. legroi (De Wit) Rataj.

Material: Cult.: NJ 2957.

This is a triploid cytotype of the form with a broad collar zone which formerly has been recorded with $2 n=28$. The taxonomic relationships between $C$. walkeri and $C$. lutea have been problematic, the main character being the collar zone versus a pronounced collar. However, a renewed study of the available material proved that it is not possible to distinguish between the various forms.

\section{Cryptocoryne wendtii De Wit $2 n=28,42$}

Material: $2 \mathrm{n}=28$. Sri Lanka: Uhomia, Kurunegala to Negumbo, leg. Windelov (= NJ 3211, 3212); Vigaya Para, Anuradhapura, leg. Windeløv (= NJ 3213); Malvatu Oya, Anuradhapura, leg. Windelov $(=$ NJ 3214-3217); Attwa, Kurunegala to Puttalam, leg. Windeløv ( $=$ NJ 3220); Ride Bandi Ella, Dendru Oya, leg. Windelev (= NJ 3221, 3222). Cult.: NJ 2930; NJ 2959; NJ 3106.

$2 n=42$. Sri Lanka: Galgamuwa, Mi Oya, leg. Windeløv (=NJ 3210); Nikowerotiya, Kurunegala to Puttalam, leg. Windelev (= NJ 3218); Talgalla, Maho to Padeniya, leg. Windelov (= NJ 3219).

\section{Cryptocoryne undulata Wendt $2 n=28,42$}

C. willisii Baum, $C$. axelrodii Rataj.

Material: $2 \mathrm{n}=28$. Cult.: NJ 3178; NJ 3179; NJ 3231. $2 \mathrm{n}=42:$ Cult.: NJ 3232 .

\section{Cryptocoryne $X$ willisii Reitz $2 \mathbf{n}=\mathbf{2 8}$}

C. nevillii auct. (see Jacobsen 1976), C. lucens De Wit.

Material: Cult: Bast 28.

Hybridization experiments have shown that $C . \times$ willisii is a hybrid complex with $C$. beckettii/C. walkeri as one of the parents and $C$. parva as the other (Jacobsen 1981). 
Cryptocoryne nevillii Hook. f. $2 n=28$

Non C. nevillii auct. (see Jacobsen 1976).

Material: Sri Lanka: 25 miles N Batticaloa, Nicolson 4268 (= NJ 3093).

There has been some uncertainty regarding the identity of this species (cf. Jacobsen 1976, 1981). However, since the collection made by Kundu \& Balakrishnan (no. 185), near Batticaloa in 1970, several other collections have been made in this part of the island, (e.g. Davidse \& Sumithrarachchi 9032 , at milepost 25 from Batticaloa towards Trincomalee) and they show that the conclusions in Jacobsen (1976) were correct. The specimens collected by Nicolson were fruiting plentifully.

\section{Cryptocoryne moehlmannii De Wit $2 n=30$}

Material: Sumatra: Simpang Empat and Sasok, leg. Jähn (= NJ $3088=$ Bast 285).

Cryptocoryne longicauda Engl. $2 \mathrm{n}=30$

C. caudata N.E. Br., C. johorensis Engl.

Material: Malaysia, Johore: Gunong Pulai, leg. Bogner (= NJ 3109). - Sarawak: Sg. Dor, NJ 78-13; Kpg. Tekalong, NJ 78-17; Sg. Engkramut, NJ 78-21; Kgp. Stutong, NJ 78-47; E of Serian, NJ 78-48. - Cult.: Bast 208.

Arends \& Laan (1979) reported the same number.

The authors agree with Rataj (1975) that $C$. longicauda and $C$. caudata are conspecific. The correct name is C. longicauda Becc. ex Engl., as Beccari's drawing in FI is unambiguous and sufficient as type material.

Material recently collected by Bogner at Gunong Pulai has flowered in cultivation and proven to be identical to material from Sarawak.

Cryptocoryne gasseri $N$. Jacobsen $2 n=34$

Material: Cult.: Bast $374=$ NJ 3102.

Jacobsen $(1979 \mathrm{a}, \mathrm{b})$ erroneously reported the chromosome number as $2 \mathrm{n}=30$ for $C$. gasseri.

\section{Cryptocoryne amicorum De Wit \& N. Jacobsen sp. nov.} $2 n=34$

C. scurrili De Wit et $C$. gasseri $\mathbf{N}$. Jacobsen satis similis. Foliorum laminae cordatae, bullosae, ad $10 \mathrm{~cm}$ longae, gramineo colore. Spatha circiter $4 \mathrm{~cm}$ longa, tubo circiter $1 \mathrm{~cm}$ longo, limbo circiter $2 \mathrm{~cm}$ longo, vitellino colore, aggerculis rubris irregulariter transversis notato.

Typus: W.J.J.O. de Wilde s.n. (= WAG 79-231 $=$ Bast $368=$ NJ 3110), Atjeh, N Sumatra (C holotypus, WAG isotypus).

Material: Sumatra: Atjeh, Bast 368.
Cryptocoryne scurrilis De Wit $2 n=68$

Material: Cult.: NJ 3070; Bast 395.

Jacobsen $(1979 \mathrm{a}, \mathrm{b})$ erroneously reported the chromosome number as $2 \mathrm{n}=60$ for $C$. scurrilis.

Cryptocoryne minima Ridley $2 n=34$

Material: Cult.: NJ 3103; NJ 78-66; NJ 78-68.

Cryptocoryne griffithii Schott $2 n=34$

Material: Cult.: NJ 3224.

Cryptocoryne zukalii Rataj $2 \mathrm{n}=\mathbf{3 4}$

Material: Cult.: NJ 3162.

Cryptocoryne jacobsenii De Wit $2 n=34$

Material: Cult.: NJ 2997; NJ 3131.

Cryptocoryne diderici De Wit $2 n=34$

Material: Cult.: NJ 78-67.

\section{Cryptocoryne cordata Grift. $2 n=34,68,85,102$}

C. blassii De Wit, $C$. evae Rataj var, evae, $C$. evae Rataj var. recordata Rataj, $C$. kerrii Gagnep., $C$. siamensis Gagnep., $C$. stonei Rataj.

Material: $2 \mathrm{n}=34$. Thailand: $\mathrm{Sg}$. Kolok, $\mathrm{N}$ of Naratiwat, leg. Scholler (= NJ 3238). - Malaysia, Johore: Masai, NJ 78-54; Sg. Sedeli, NJ 78-57; 37 mile stone from Kota Tinggi towards Mersing, NJ 78-58. - Cult.: NJ 3004; NJ 3021.

$2 n=68$ : Malaysia, Kedah: Penang Kedah, leg. Tomey, (= Bast 295). - Cult.: NJ 2907; NJ 3104; NJ 3124; NJ 3144; Bast 16.

2n $=85$ : Cult.: Bast 18; Bast 341; Bast 343; Bast 358; NJ 3121 .

2n = 102: Thailand: Lam Kalu, leg. Horst, (= NJ 3146). Cult.: P 1969/218; NJ 3041; NJ 3145; K.E.N. 102.67; Bast 344.

This species has been of much debate. The type (Griffith $1112, K$, isotype at $P$ ) is well preserved, but with a somewhat undefinable brownish colour because of drying and age. It has the typical broad collar zone on the limb of the spathe. The protoloque says "Lamina [of the spathe]... colore ut videtur purpurecenti-viridis,...", which has been interpreted as the limb being purple. However, the form and the remaining colours of the limb of the type specimen correspond to those found in the common Malayan plant with the yellow limb of the spathe. Many cultivated specimens, mostly of unknown origin, sometimes have a more or less pronounced purplish to brownish tinge towards the margin and the apex, sometimes covering most of the surface outside the collar zone. The material available suggests that $C$. cordata s. str. may be interpreted as a diploid, and what has been called e.g. C. siamensis and $C$. blassii are to be regarded as tetraploid or hexaploid forms (see 
e.g. Jacobsen 1977). The pentaploid cytotypes, all of unknown origin, have rather broad leaves, which, however, are also found in e.g. diploid forms.

Among the above cited collections, as well as in the herbarium specimens studied (of the above cited taxa, 44 collections from B, BM, E, L, K, US, and SING), no character or character combination could be found that could distinguish the different forms. The colour, shape, and size of the leaves, the colour and shape of the limb of the spathe, and the shape of the stigmas were found to vary continuously.

Although the distribution of the various cytotypes on the Malay peninsula is still unknown, as is the origin of the cultivated material, the facts indicate that the complex should be interpreted as consisting of one species with different cytotypes.

\section{Cryptocoryne zonata De Wit $2 n=68$}

Material: Malaysia, Sarawak: Sg. Engkramut, NJ 78-20. Brunei: Badas River, leg. Bogner (= NJ 3108$)$; Sg. Lumut (?), Bast 11.

\section{Cryptocoryne grabowskii Engl. $2 n=68$}

C. grandis Ridl.

Material: Malaysia, Sarawak: road to Matang, NJ 78-26.

The collection from Matang was probably collected at or near the type locality of $C$. grandis. The type of $C$. grabowskii (B) consists of only one leaf and a spathe, of which the spadix is missing. However, the form and the structure of the limb of the spathe in the type of $C$. grabowskii cannot be distinguished from $C$. grandis from Matang.

\section{Cryptocoryne edithiae De Wit $2 n=68$}

Material: Indonesia, Kalimantan: $\mathbf{N}$ of Sanpit, leg. Korthaus ( $=$ N] 3082).

\section{Cryptocoryne schulzei De Wit $2 n=34$}

Material: Malaysia, Johore: $\mathbf{4 3}$ mile stone from Mersing towards Kluang, NJ 78-60; 48 mile stone from Mersing towards Kluang, NJ 78-61.

\section{Cryptocoryne nurii Furtado $2 n=34$}

Material: Malaysia, Johore: 32 mile stone from Mersing towards Kluang, NJ 78-59; Sg. Kahang, NJ 78-62. - Cult.: NJ 3043.

\section{Cryptocoryne affinis Hook. $1.2 \mathrm{n}=34$}

C. haerteliana Milk.

Material: Cult.: NJ 2936.
Cryptocoryne ferruginea Engl. $2 n=34$

C. pontederiifolia Schott ssp. sarawacensis Rataj; $\boldsymbol{C}$. sarawacensis (Rataj) Jacobsen.

Material: Malaysia, Sarawak: 12.5 mile stone W of Batu Kitang, NJ 78-35, NJ 78-36, NJ 78-37; Stapok F.R., NJ 78-44. - Cult.: NJ 78-25.

The collection from Stapok had large, green leaves $(15-30 \mathrm{~cm})$ while the plants from Batu Kitang were smaller $(10-15 \mathrm{~cm})$ and had darker markings on the leaves (see also Schulze 1971, sub C. pontederiifolia). There was also a slight difference in the shape of the spathe in plants from the two localities, as the spathes from Stapok were more slender, with a purple tinge on the outside, and the spathes from Batu Kitang were "thicker" and more whitish on the outside.

The specimens collected in Sarawak in 1978 could have glabrous as well as hairy leaves. This character makes it clear that $C$. sarawacensis is identical to the hitherto little-known C. ferruginea (Jacobsen 1980b).

\section{Cryplocoryne tortilis De Wit $2 n=34$}

Material: Cult.: ex Wageningen, NJ 2953; ex Sadilek, NJ 3078.

The material of NJ 2953 originates from Wageningen and is probably part of the type collection of C. tortilis, probably the same that was counted by Legro (De Wit 1971).

\section{Cryptocoryne fusca De Wit $2 n=34$}

Material: Indonesia, Kalimantan: Mindor River, leg. Tomey (= Bast 294 = NJ 3114); Domlo Kapuas, leg. Tomey, (= Bast 330).

C. fusca is no doubt closely related to $C$. tortilis, there being only minor differences in the spathe, the former having a shorter tube. A closer study may reveal that they are to be regarded as forms of the same species.

Cryptocoryne auriculata Engl. $2 \mathrm{n}=\mathbf{3 4}$

Material: Malaysia, Sarawak: Sg. Entabai, NJ 78-6; Sg. Selalang, NJ 78-9. - Cult.: Nj 3074.

\section{Cryptocoryne bullosa Engl. 2n $=34$}

Material: Malaysia, Sarawak: Sg. Sibriak, NJ 78-7; Sg. Entabai, NJ 78-24.

C. bullosa has not flowered in cultivation, as it is rather difficult to grow. Little is known about the variation of the colour and structure of the limb of the spathe of $C$. bullosa, as flowering material from nature is scarce. A photograph can be found in van der Vlugt (1970). The leaf morphology resembles that of $C$. keei and the unidentified Cryplocoryne from Banjermasin. 
Cryptocoryne pygmaea Merrill $2 n=34$

Material: Philippine Islands: NJ 2962.

The material was received together with a shipment of C. usteriana Engl. from the Philippine Islands in 1975. The leaves had an olive-brown colour with darker markings.

Rataj's neotype, Ebalo 717 (GH, isotypes at PNH and $\mathrm{MO}$ ), is a rather small form. It is similar to Merrill 9272 (K, US) and Ramos \& Edano 37040 (BM, K, L) and to NJ 2864 that represent forms with somewhat larger leaves.

Cryptocoryne lingua Engl. $\quad 2 n=36$

C. spathulata Engl.

Material: Malaysia, Sarawak: 12.5 mile stone W of Batu Kitang, NJ 78-38; Batu Kitang, NJ 78-40. - Cult.: NJ 78-33.

Cryptocoryne alba De Wit $2 n=36$

Material: Cult.: NJ 3029; NJ 3172.

The shapes of the leaves and the spathes suggest that $C$. alba is closely related to $C$. thwaitesii.

Cryptocoryne bogneri Rataj $2 n=36$

Material: Cult.: NJ 3101.

Cryptocoryne albida Parker $2 n=36$

Material: Thailand: Bań Wangyon, NJ 77-81 f.

Cryptocoryne crispatula Engl. $2 n=36$

Material: Thailand: Phu Khieo, NJ 77-37,-Cult.: P 1963/626; P 1963/631.

\section{Cryptocoryne retrospiralis (Roxb.) Kunth $2 n=36$}

Material: India: Poona River, leg. Cook (= NJ 3126); Poona River, leg. Cook (= NJ 3128); Poonoor River, leg. Cook (= NJ 3130); Thuta, Palghat Distr., Sivadasan CU 21481.

\section{Discussion}

\section{Subdivision of the genus Cryptocoryne}

In this and the earlier studies (Jacobsen 1976, 1977), about $90 \%$ of the species, as presently recognized, have been investigated. In regard to chromosome number it is clear that several species comprise different cytotypes. In combination with the geographical distribution and the main features of the morphology of the various taxa, these chromosome numbers provide a basis for the grouping of the species presented in the appendix.
In the survey of the groups in the appendix, the leaves are not described in detail. Leaf-morphology is characteristic for each species, but an accurate description of the leaves of a given species can only be given in very elaborate descriptions.

Based on the morphology, the following can be postulated about the 7 species from which living plant material has not yet become available. $C$. decus-silvae De Wit obviously belongs to the $C$. purpurea group (2n $=34$ ). . elliptica Hook. $f$. appears to be closely related to $C$. schulzei $(2 \mathrm{n}=34)$, whereas the chromosome number of $C$. dewitii Jacobsen may be $2 n=34$, although it seems to be isolated morphologically. The three narrow-leaved species, $C$. consobrina Schott (India), $C$. cognata Schott (India), and $C$. cruddasiana Prain (Burma) have morphological similarities to both the $C$. albida group and to $C$. spiralis. However, judging from the material available, it seems that each of the three species may form the basis for separate groups. Finally, C. gomezii Schott (Bangladesh) is unique in its flower structure, having non-fused female flowers and a limb of the spathe resembling those encountered in the genus Lagenandra.

\section{Cytological differentiation}

Cryptocoryne constitutes, next to the genus Lagenandra, the well defined subtribe Cryptocoryninae in the tribe Areae (cf. Engler 1920). The differences from Lagenandra can be interpreted as adaptations to aquatic conditions. In regard to most characters it is a question of reductions to simpler or missing structures. Hence it is obviously relevant to compare the present observations in Cryptocoryne with the ones made in Lagenandra.

Without exception, the somatic number is $2 n=36$ for the species of Lagenandra (Marchant 1972, Arends \& Van der Laan 1979, Jacobsen, unpubl.). The same number, $2 n=36$, is found in three species groups of Cryptocoryne. One of them, the $C$. thwaitesii group, is endemic to Sri Lanka where the majority of the species of Lagenandra occur. Therefore, it is likely that the primitive chromosomal condition in the genus (as compared to Lagenandra) is $2 \mathrm{n}=36$.

From the somatic numbers, a heteroploid series, as based on the numbers of $x=10$ (from $2 n=20$ ); $x=11$ (from $2 n=22,33,66,88,132) ; x=14$ (from $2 n=28$, 42); $x=15$ (from $2 n=30$ ); $x=17$ (from $2 n=34,68$, 85,102 ); and $x=18$ (from $2 n=36,54,72$ ), can be defined. No matter how the morphological or evolutionary trends in Cryptocoryne have developed, it is necessary to explain or correlate them with the origin of the aneuploid series. The various euploid series can easily be seen as a secondary development by the mechanism of chromosome doubling.

Heteroploid series in genera of the Araceae are not very common, but a case similar to Cryptocoryne is, as far as known, represented by the genus Biarum with 
approximately 14 species (Riedl 1980). The chromosome numbers of $2 \mathrm{n}=16,22,24,26$, ca. 96 have been reported for Biarum (Marchant 1972, Monti \& Garbari 1974, Talavera 1976).

Following Engler's (1920) treatment, there appears to be a certain correlation between the chromosome numbers and the taxonomy. The range of numbers in Biarum is different from that found in Cryptocoryne but, when comparing them with the remainder of the Areae, it is most probable that the base number is of secondary origin. However, a reduction to $x=8$ comes close to the primary base numbers found in the whole of the Araceae (cf. Marchant 1973).

It is difficult to point at any of the known groups in Cryptocoryne with $2 \mathrm{n}=36$ as being more primitive than the others. If one group has to be suggested, on the basis of morphology and distribution, it would be the $C$. thwaitesii group.

Clear relationships between species from different geographical areas appear to be rather few and are probably found only in the $C$. cordata and the $C$. purpurea groups (Malay peninsula and Borneo). C. longicauda is found in Borneo and on the Malay peninsula.

By assuming that the chromosomal evolution has taken place from a high number to a lower number, i.e. from 36 towards 20 , one gets a sequence that is the reverse of the one according to which the species are arranged in this and previous papers (appendix). The main groupings, however, remain the same. It is difficult to indicate or argue in favour of closer connections (except in a few cases) between the groups.

Acknowledgements - Living material has most kindly been provided by C. D. K. Cook, Zurich; R. A. Gasser, Florida; L. J. G. van der Maessen, India; F. Möhlmann, BRD; D. Nicholson, Washington D.C.; V. Sadilek, Bmo; M. Sivadasan, Calicut; and $\mathrm{H}$. Windelov, Aarhus. The curators of the previously mentioned herbaria have most kindly provided material for study. Jacobsen's journey to Malaysia was financed by "Carlsbergs Mindelegat for Brygger J. C. Jacobsen" which is greatfully acknowledged. J. Bogner, Munich, was an always inspiring travelling companion on the trip to Borneo and West Malaysia in September 1978. We are much in debt to Mr. Henry Ong, Kuching, who took care of us during our stay in Sarawak. Mr. Lim Kim Kiat, Singapore, was of much help during our stay in Singapore and Johore. The skilful technical assistance by $\mathbf{G}$. Andersen, S. Danbæk, K. Jensen, L. Knudsen, and $Y$. Madsen is greatly acknowledged. Handelskwekerij P. L. van Loon b.v., The Netherlands and The Danish Natural Science Research Council have made the printing of the colour plates possible. Tyge Christensen kindly provided the Latin descriptions.

\section{Appendix}

Subdivision of the genus Cryptocoryne on the basis of geographical distribution, morphology, and chromosome numbers. $\mathbf{2 n}=\mathbf{2 0}$

1. The C. striolata group

The group is characterized by the absence of a collar on the limb of the spathe, but there is a coloured collar zone. Leaves narrowly ovate to ovate. Fig. $2 \mathrm{~A}$.

Species. C. striolata (Fig, 2A), Borneo, $2 n=20 ;$ C. keei, Borneo, $2 \mathrm{n}=20$.

$2 \mathrm{n}=22,33,66,88,132$

2. C. ciliata

The species is characterized by the ciliate margin of the limb of the spathe. Leaves narrowly ovate. Illustration, see Jacobsen 1977.

Species. C. ciliata, Asia, $2 \mathrm{n}=22,33$.

3. C. spiralis

The species is characterized by the long, curved limb of the spathe with its horizontal ridges. Leaves linear. Ilustration, see Jacobsen 1977.

Species. C. spiralis, India, $2 \mathrm{n}=33,66,88,132$.

$2 n=28,42$

4. The C. beckettii group

The group is characterized by the long tube (except $C$. parva) and the prominent collar (except forms of $C$. walkeri) of the limb of the spathe. Leaves narrowly ovate. Fig. 2B, and Jacobsen 1976.

Species. $C$. beckettii, Sri Lanka, $2 n=28,42 ;$ C. walkeri, Sri Lanka, $2 n=28,42 ; C$. wendtii, Sri Lanka, $2 n=28,42 ; C$. undulata, Sri Lanka, $2 n=28,42 ; C$. parva, Sri Lanka, $2 \mathrm{n}=$ 28; C. $\times$ willisii, Sri Lanka, $2 \mathrm{n}=28$; C. nevellii (Fig. $2 \mathrm{~B}$ ), Sri Lanka, $2 \mathrm{n}=28$.

$\mathbf{2 n}=\mathbf{3 0}$

5. The $C$. pontederiifolia group

The group is characterized by the short spathe with a prominent collar. Cataphylls always present. Leaves cordate. Fig. 2C, and Jacobsen 1977.

Species. $C$. pontederiifolia, Sumatra, $2 \mathrm{n}=30 ; C$. moehlmannii (Fig. 2C), Sumatra, $2 \mathrm{n}=30$.

\section{C. villosa}

The species is characterized by the ciliate surface of the limb of the spathe and the purple-spotted collar zone. Leaves cordate. Fig. 2G, and Jacobsen 1980c.

Species. C. villosa (Fig. 2G), Sumatra, $2 \mathrm{n}=30$.

\section{C. longicauda}

The species is characterized by the long caudate limb of the spathe and the pronounced collar. Leaves cordate. Fig. $2 \mathrm{~F}$.

Species. C. longicauda (Fig. 2F) Borneo, Johore, $2 \mathrm{n}=30$. 

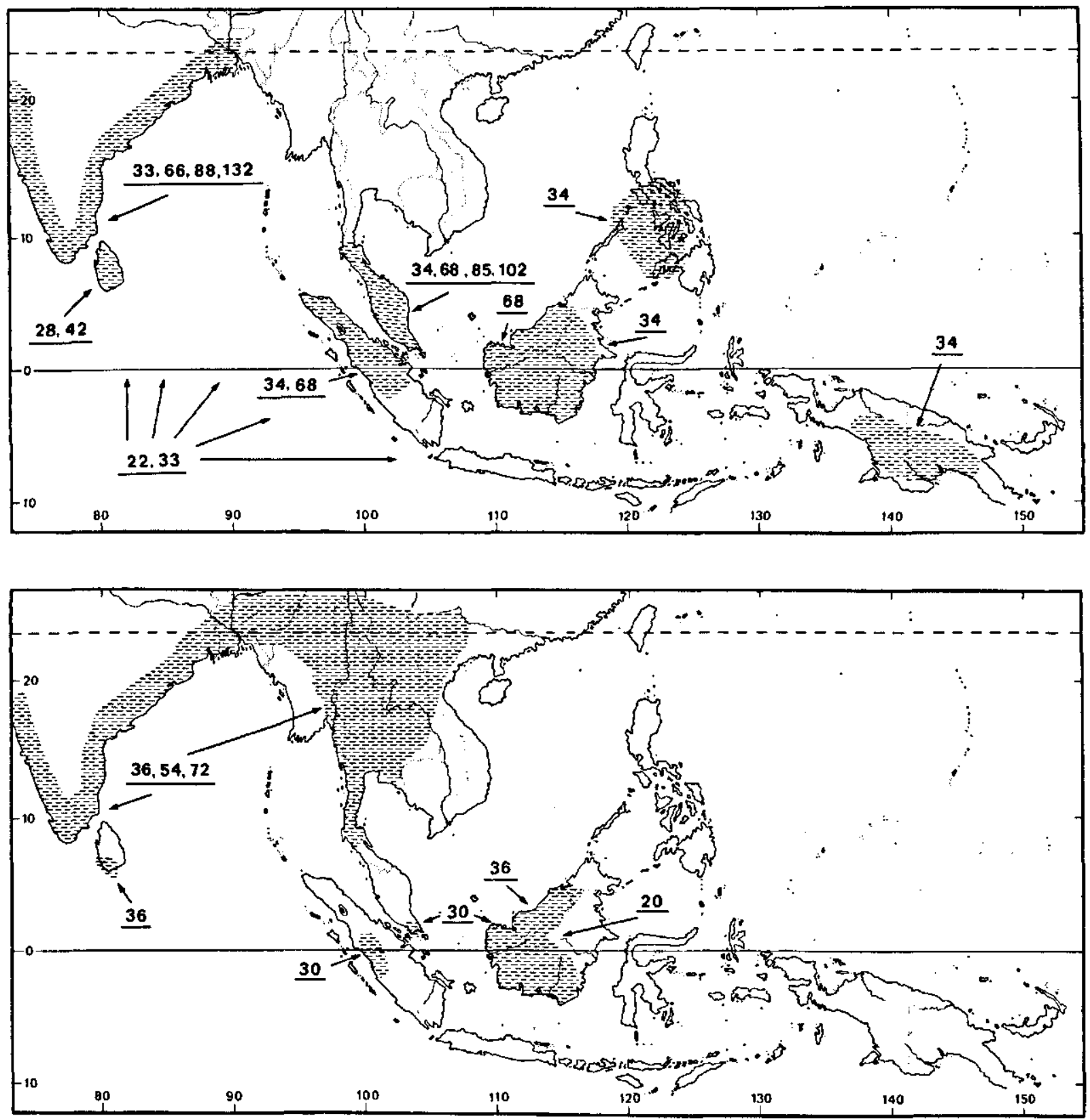

Fig. 1. Distribution of the various chromosome numbers in Cryptocoryne.

\section{$2 \mathrm{n}=34,68,85,102$}

8. The $C$. scurrilis group

The species are characterized by the very narrow opening of the collar of the limb of the spathe. Leaves narrowly ovate to cordate. Fig. 3C, E, F.

Species. C. gasseri (Fig. 3C), Sumatra, $2 \mathrm{n}=34 ; C_{\text {. amicorum }}$ (Fig. 3E), Sumatra, $2 n=34 ; C$. scurrilis (Fig. 3F, Sumatra, 2n $=68$.

\section{The C. griffithii group}

The species are characterized by the prominent collar and the rough surface of the limb of the spathe. Leaves cordate. Illustration, see Jacobsen 1977.

Species. $C$. minima, Malay peninsula, $2 \mathrm{n}=34 ; C$. zewaldiae, Malay peninsula, $2 \mathrm{n}=34 ; \boldsymbol{C}$. griffuhii, Malay peninsula, $2 \mathrm{n}=$ 34. 

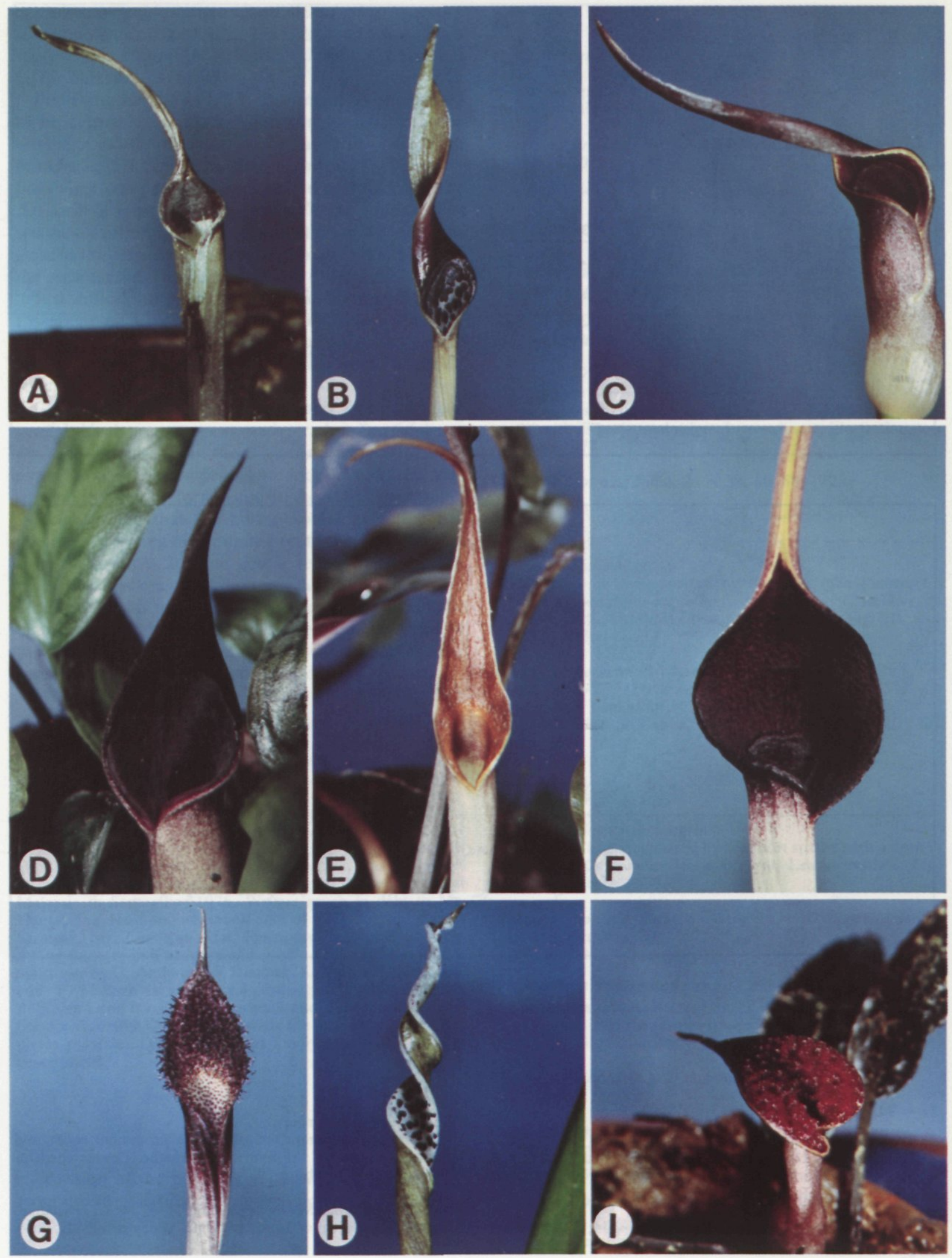

Fig. 2. A. Cryptocoryne striolata (NJ 78-52). - B. C. nevillii (NJ 3093). - C. C. moehlmannii (NJ 3088). - D. C. auriculata (NJ 78-6). - E. C. zukalii (NJ 3162). - F. C. longicauda (NJ 78-21). - G. C. villosa (NJ 3107). - H. C. retrospiralis (NJ 3126). - I. C. nurii $(\mathrm{NJ} 78-62)$. All $\times 2$. 


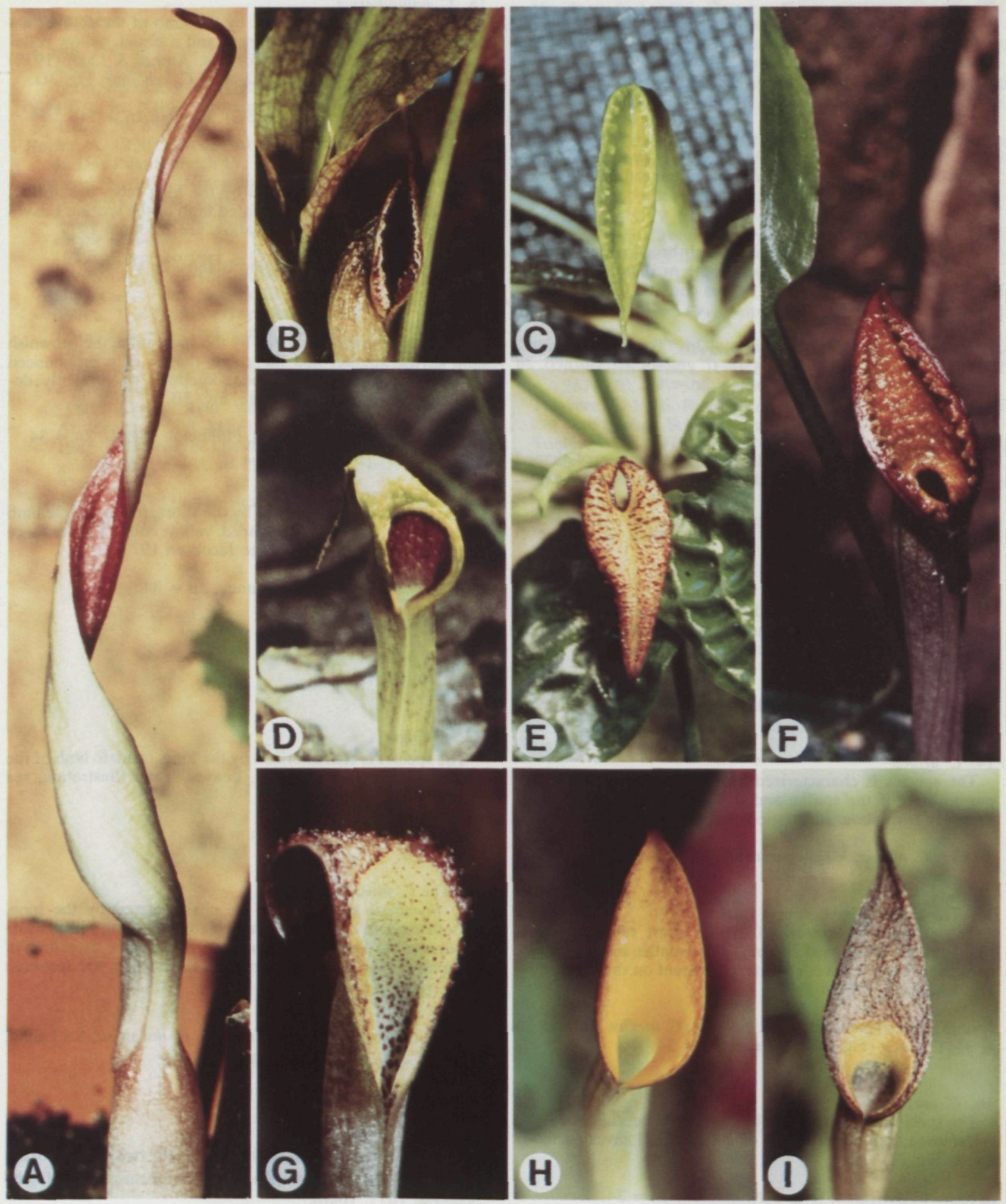

Fig. 3. A. Cryptocoryne fusca (Bast 294). - B. C. pygmaea (NJ 2962). - C. C. gasseri (NJ 3071). - D. C. schulzei (Bogner 364). E. C. amicorum (Bast 368). - F. C. scurrilis (Bast 395). - G. C. pallidinervia (Bast 104). - H. C. zonata (NJ 78-20). - I. C. edithiae (NJ 3082). All $\times 2$ (C, E, Gasser phot.; D, Bogner phot.; I, Möhlmann phot.). 
10. The $C$. purpurea group

The species are characterized by the more or less prominent collar zone and the rough surface of the coloured limb of the spathe. The group may be rather closely related to the $C$. cordata and the $C$. griffithii groups. Leaves cordate. Fig. 2E, and Jacobsen 1977.

Species. C. purpurea, Malay peninsula, $2 \mathrm{n}=34$; C. zukalii (Fig. 2E), Malay peninsula, $2 \mathrm{n}=34$; $C$. jacobsenii, Malay peninsula, $2 n=34 ; C$. diderici, Malay peninsula, $2 n=34$.

\section{The $C$. cordata group}

The species are characterized by their broad collar zone, or slightly indicated collar, and the smooth or slightly rough surface of the limb of the spathe. Leaves cordate. Fig. $3 \mathrm{H}$, I, and Jacobsen 1977.

Species. $C$. cordata, Malay peninsula, $2 n=34,68,85,102 ; C$. zonata (Fig. 3H), Borneo, $2 \mathrm{n}=68 ;$ C. grabowskii, Borneo, $2 \mathrm{n}$ $=68 ; C$. edithiae (Fig. 3I), Borneo, $2 n=68$.

\section{C. schulzei}

The species is characterized by the peculiar funnel-shaped limb of the spathe with the dark collar. Leaves narrowly ovate. Fig. 3D.

Species. C. schulzei (Fig. 3D), Malay peninsula, $2 n=34$.

\section{C. nurii}

The species is characterized by the extremely rough protuberances and the dark red surface of the limb of the spathe and the narrow opening of the collar. Leaves narrowly ovate. Fig. 2I.

Species. C. nurii (Fig. 2I), Malay peninsula, $2 n=34$.

\section{C. affinis}

The species is characterized by the spirally-twisted, darkpurple limb of the spathe and the prominent collar. Leaves narrowly lanceolate. Illustration, see Jacobsen 1977 .

Species. C. affinis, Malay peninsula, $2 \mathrm{n}=34$.

\section{The $C$. ferruginea group}

The group is characterized by the short tube, the long, rough, more or less caudate limb of the spathe and the prominent collar zone. Leaves cordate, pubescent on the lower side. Fig. 3A, and Jacobsen 1977.

Species. $C$. ferruginea, Borneo, $2 n=34 ; C$. tortilis, Borneo, $2 n$ $=34$; $C$. fusca (Fig. 3A), Borneo, $2 \mathrm{n}=34$.

\section{C. auriculata}

The species is characterized by the short tube, the broad, red collar zone, and the red limb of the spathe. Leaves narrowly ovate. Fig. 2D.

Species. C. auriculata (Fig. 2D), Borneo, $2 \mathrm{n}=34$.

\section{C. bullosa}

The species is characterized by the short tube, the prominent, dark purple collar, and the rugose, purplish limb of the spathe. Leaves narrowly ovate, strongly bullate.

\section{C. pallidinervia}

The species is characterized by the limb of the spathe that has prominent, red protuberances and a broad, yellow collar zone with red spots. Leaves cordate. Arends \& Laan (1979) reported $2 n=34$ under the name of $C$. venemae. Fig. 3G.

Species. C. pallidinervia (Fig. 3G), Borneo, $2 n=34$.

\section{C. usteriana}

The species is characterized by the long tube, the distinct collar zone and the purple, twisted limb of the spathe. Leaves linear to ovate, bullate. lliustration, see Jacobsen 1977.

Species. C. usteriana, Philippine Islands, $2 n=34$.

\section{C. pygmaea}

The species is characterized by the short tube, the brownish limb of the spathe, and the collar that is only pronounced towards the front of the tube, sometimes only slightly developed. Leaves narrowly ovate. Fig. 3B.

Species. C. pygmaea (Fig. 3B), Philippine Islands, $2 \mathrm{n}=34$.

\section{C. versteegii}

The species is characterized by the short, rough, purple limb of the spathe, and the pronounced, yellow collar. Leaves more or less cordate. Illustration, see Jacobsen 1977.

Species, $C$, versteegii, New Guinea, $2 \mathrm{n}=34$.

$2 n=36,54,72$

\section{C. lingua}

The species is characterized by the long, caudate limb of the spathe and the lacking colfar. Leaves ovate. lllustration, see Jacobsen 1977.

Species. C. lingua, Borneo, $2 \mathrm{n}=36$.

\section{The $C$. thwaitesii group}

C. thwaitesii and $C$. alba are characterized by the long, smooth caudate limb of the spathe and the lacking collar, while C. bogneri has a pronounced rough surface on the short limb of the spathe. Leaves ovate to cordate. Illustration, see Jacobsen 1977,1979 a.

Species. C. alba, Sri Lanka, $2 \mathrm{n}=36 ;$ C. thwaitesii, Sri Lanka, $2 \mathrm{n}=36 ;$ C. bogneri, Sri Lanka, $2 \mathrm{n}=36$.

\section{The $C$. albida group}

The group is characterized by the spirally twisted limb of the spathe and the lacking collar. Leaves linear. Fig. $2 \mathrm{H}$, and Jacobsen 1977, 1980a.

Species. $C$. albida, $\mathrm{S}$ Thailand, $2 \mathrm{n}=36 ; \mathrm{C}$. crispatula, IndoChina, $2 n=36,54 ; C$. retrospiralis (Fig. $2 H$ ), India, $2 n=36$, 72.

Species. C. bullosa, Borneo, $2 \mathrm{n}=34$. 


\section{References}

Arends, J. C. \& F. M. van der Laan, 1978. Somatic chromosome numbers in Lagenandra Dakell. - Meded. Landbouwhogeschool Wageningen 13: 46-48.

- 1979. In IOPB chromosome number reports LXV. Taxon 28: 636-637.

Engler, A. 1920. Araceae-Aroideae und Araceae-Pistioideae, in Das Pflanzenreich IV, 23 F. - Leipzig.

Jacobsen, N. 1976. Notes on the Cryptocoryne of Sri Lanka (Ceylon). - Bot. Notiser 129: 179-190.

- 1977. Chromosome numbers and taxonomy in Crypto. coryne (Araceae). - Bot. Notiser 130: 71-87.

- 1979a. Cryptocoryner. - Copenhagen.

- 1979b. Cryptocoryne gasseri N. Jacobsen, sp. nov. (Araceae). - Bot. Notiser 132: 114.

- 1980a. The Crypiocoryne albida group of mainland Asia (Araceae). - Meded. Landbouwhogeschool Wageningen 19: 183-204.

- 1980b. Does Cryptocoryne ferruginea flower at full moon? - Aroideana 3: 111-116.

- 1980c. Cryptocoryne villosa N. Jacobsen, sp. nov. Aroideana 3: 109, 118-119.

- 1981. Cryptocoryne undulata Wendt und Bemerkungen zu anderen Arten. - Aqua Planta 81: 29, 31-37. Nachschrift, 92-94.

Jacobsen, P. 1957. The sex chromosomes in Humulus. Hereditas 43: 357-370.
Marchant, C. J. 1972. Chromosome variation in Araceae: IV. Areae. - Kew Bull. 26: 395-405.

- 1973. Chromosome variation in Araceae: V. Acoreae to Lasieae. - Kew Bull. 28: 199-210.

Monti, C. \& F. Garbari, 1974. Appunti citotassonomica sul genera Biarum Schott (Araceae) in Italia. - Giorn. Bot. Ital. 108: 19-26.

Ostergren, G. \& Heneen, W. K. 1962. A squash technique for chromosome morphological studies. - Hereditas 48: 332-341.

Rataj, K. 1975. Revision of the genus Cryptocoryne Fischer. Studie CSAV, č. 3: 1-174. Praha.

Riedl, H. 1980. Tentative keys for the identification of species in Biarum and Emnium, with notes on some taxa included in Biarum. - Aroideana 3: 24-31.

Sarkar, A. K., Dutta, N. \& Chatterjee, U. C. 1979. Chromosome studies in Cryptocoryne (Araceae). - Caryologia 32: $1-4$.

Schulze, J. 1971. Cryptocorynen aus Sarawak I-IV. - Die Aquarien und Terrarien Zeitschrift 24: 230-233, 267-270, 303-306, 336-339.

Talavera, S. 1976. Revision de las especies espanolas del genero Biarum Schott. - Lagascalia 6: 275-296.

Tomey, W. A. 1978. Twee Cryptocorynen van Upper Sadong in Sarawak, Noord Borneo. - Het Aquarium 48: 287-288.

Vlugt, P. J. van der, 1970. Cryptocoryne bullosa. - Het Aquarium 41: 86-88.

Wit, H. C. D. de, 1971. Aquarienpflanzen. - Stuttgart. 